\title{
CHEMICAL OXYGEN DEMAND REDUCTION FROM COFFEE PROCESSING WASTE WATER - A COMPARATIVE STUDY ON USAGE OF BIOSORBENTS PREPARED FROM AGRICULTURAL WASTES
}

\author{
RAMYA P.M. ${ }^{1}$ \\ JAYASRAVANTHI M. ${ }^{2}$ \\ DULLA B.J. ${ }^{3}$ \\ VENKATA N.R. ${ }^{3, *}$
}

\author{
${ }^{1}$ Department of Chemistry, ANUCET, Acharya Nagarjuna University \\ Guntur - 522510, India \\ ${ }^{2}$ Department of Biotechnology, Acharya Nagarjuna University \\ Guntur - 522510, India \\ ${ }^{*} 3$ School of Biotechnology, Vignan's University \\ Vadlamudi - 522213, India
}

Received: 02/08/2014

Accepted: 23/04/2015

Available online: 28/04/2015 *to whom all correspondence should be addressed: e-mail: doctornadh@yahoo.co.in

\section{ABSTRACT}

The utilization of three novel and distinct agricultural waste materials, namely casuarina fruit powder (CFP), sorghum stem powder (SSP) and banana stem powder (BSP) as low cost adsorbents for reducing chemical oxygen demand (COD) levels of coffee industry wastewater has been examined. Prepared adsorbents were characterized by scanning electron microscopy (SEM), Energy-dispersive $x$-ray spectroscopic (EDAX) and Fourier Transform Infrared Spectroscopy. The effects of parameters like adsorbent dose, $\mathrm{pH}$, temperature, agitation rate and time of adsorption on the reduction of COD levels were analyzed for each adsorbent individually and the efficiency order is CFP>SSP>BSP. Based on the extent of compatibility to Freundlich/Langmuir adsorption isotherm and different models (pseudo-first order and second order, Boyd, Weber's and Elovich), simultaneous occurrence of chemisorption and physisorption was proposed. Based on the observations, it is proposed that three kinetic stages involve in adsorption process viz., diffusion of sorbate to sorbent, intra particle diffusion and then establishment of equilibrium. As these three adsorbents exhibit adsorption capacity more than $80 \%$, the adsorbents prepared from agricultural wastes have promising role towards reduction of COD from industrial wastewater to contribute environmental protection.

Keywords: Coffee industry waste water, COD, adsorption, casuarinas fruit, sorghum stem, banana stem

\section{Introduction}

Coffee is ranked second among traded commodities, where India has a share of $4.5 \%$ in global market and dictates the export economy. But, coffee marketing is facing environmental and social issues (Tallontire, 2002). In wet coffee processing procedure, removal of pulp (de-pulping) consumes more than half of the water required for entire process (Fresner and Schnitzer, 1996). One tonne of processed coffee results in pollution equivalent to $45 \mathrm{~kg}$ COD or $273 \mathrm{~m}^{3}$ of crude domestic sewage (Calzada et al., 1989). Coffee processing plants generate waste water having colour and different organic molecules like pectin, fibers, fat, caffeine, polyphenols, proteins, carbohydrates (reducible and non-reducible), chlorogenic acid, and other macromolecules (lignins, tannins, humic acid) (Von Enden, 2002) which are rapidly biodegradable. Coffee processing plant effluents cause bad odor and pollution of ground water (Mburu et al., 1991). 
Depletion of dissolved oxygen and a decrease in $\mathrm{pH}$ (due to fermentation of organic matter) may hamper the sustainability of water bodies (Fresner and Schnitzer, 1996). Studies carried out by Alemayehu Haddis and Rani Devi, (2008) reveals that the consumption of water polluted with coffee processing plant causes diseases like breathing problem, nausea, stomach problem and skin irritation. The reduction of these COD levels plays an important role in the reuse of the industrial effluents (Selvamurugan et al., 2010).

As per WHO (1995) norms, COD permissible limits for irrigation is $300 \mathrm{mg} \mathrm{l}^{-1}$. Traditionally, the reduction of COD levels from industrial effluents was achieved by various biological and physico chemical techniques like fermentation, sedimentation, flocculation, coagulation etc. Hence, the minimization of COD to permissible levels is essential for the safe survival of ecosystem. Among all the reported methods, biosorption is considered as a most promising technique because it is rapid, economic and environmentally benign technology and also is not associated with the generation of secondary wastes which present treatment problems (Verma and Mishra, 2010; Ramesh et al., 2014). In several previous reports, many investigators have studied the use of various plant materials as adsorbents for the reduction of COD from waste water, such as, avocado peel or seed carbon (Rani Devi et al., 2008; Rani Devi, 2010), metakolin, dates nut carbon and tamarind nut carbon (Parande et al., 2009). Hence, in this study an attempt is made to develop low-cost, effective and commercially applicable adsorbents from agricultural wastes (casuarina fruit, sorghum stem and banana) and to study their usage for minimizing the COD levels from coffee waste water to cater the needs of developing and underdeveloped countries.

\section{Experimental}

\subsection{Materials and Methods}

The three adsorbents used for this study were (a) Casuarina fruit powder (CFP) (b) Sorghum stem powder (SSP) and (c) Banana Stem powder (BSP). The cleaned raw materials were washed with formaldehyde solution (2\%) to reduce organic leaching and prevent mould growth during batch sorption (Chen and Yang, 2005) and completely air dried. Sieves of particles (size $0.3 \mathrm{~mm}$ to $1.0 \mathrm{~mm}$ ) were used. All the chemicals used were of analytical grade. The adsorption studies were done with washings (sample was collected prior to final stage of effluent treatment in industry and used without any further processing/treatment after collection i.e., 11,300 $\mathrm{mg} \mathrm{I}^{-1}$ as Initial COD) from Continental Coffee Limited, Duggirala, Andhra Pradesh, India. The COD of the waste water samples before and after treatment with adsorbents were measured according to the methods prescribed by the ASTM (American society for testing and materials, 1972) annual book. The $\mathrm{pH}$ was adjusted using $0.1 \mathrm{M} \mathrm{HCl}$ or $0.1 \mathrm{M} \mathrm{NaOH}$.

\subsection{Adsorption studies}

The experiments were performed in batch process in Erlenmeyer flask containing $250 \mathrm{ml}$ of wastewater sample and the total volume of the reaction mixture were kept at $100 \mathrm{ml}$. The equilibrium time for adsorption was determined as 3hours and the other experiments were conducted in batch with common parameters: $37 \pm 2{ }^{\circ} \mathrm{C}$ temperature, $4 \mathrm{~g} \mathrm{I}^{-1}$ adsorbent, neutral $\mathrm{pH}$, and $200 \mathrm{rpm}$. The removal efficiency of each adsorbent with respect to different parameters like time (30-240 min), adsorbent dose (100-1000 $\mathrm{mg} / 100 \mathrm{ml}), \mathrm{pH}(3-10)$, temperature $\left(30-70^{\circ} \mathrm{C}\right)$, and speed of rotation $(50-300 \mathrm{rpm})$ was determined in individual experiments. In each experiment, the wastewater samples equilibrated with adsorbents were withdrawn, centrifuged and the residual COD concentrations were measured. The experiment was repeated thrice and average results were documented.

\section{Results and Discussion}

\subsection{SEM, EDAX and FT-IR studies}

Properties of the solute and sorbent dictate the nature of adsorption. Hence, the adsorbent characterization was done by scanning electron microscopy (Fig. 1) which visualizes the surface texture and porosity of the samples. Rough surface with lot of holes were visible in form of dark area for 
micrographs before adsorption which is an indication of large surface areas, whereas, a smooth surface with some form of cluster having ice coating can be observed after adsorption. Prior to removal of COD, the CFP sample surface consists of cavities indicating high possibility of adsorption. EDAX studies were carried out to determine the chemical composition of biosorbents (Wt\% of elements). BSP:C-62.65, O34.44, Si-1.15, Fe-0.87; CFP:C-46.84, O-40.49, Na-10.71, Si-1.51, Fe-0.45; SSP:C-61.26, O-34.69, Na$0.35, \mathrm{Si}-0.25, \mathrm{Fe}-0.22, \mathrm{Zn}-0.26$. In all the absorbents, presence of stretching for $\mathrm{C}-\mathrm{O}, \mathrm{C}=\mathrm{O}$ and aliphatic $\mathrm{C}$ $\mathrm{H}$ can be confirmed from peaks in the range of 1023-1039 cm respectively. But, additional peaks in CFP above $3000 \mathrm{~cm}^{-1}$ indicate the $=\mathrm{C}-\mathrm{H}$ stretching and further $\mathrm{C}=\mathrm{C}$ stretching can be observed from peaks in the range of 1450-1550 $\mathrm{cm}^{-1}$. Broad peaks in the range of 3305$3320 \mathrm{~cm}^{-1}$ indicate the presence of carboxylic acid groups in SSP and BSP, whereas, dominant sharp peak at $3737 \mathrm{~cm}^{-1}$ indicates phenolic groups in CFP (Fig. 2).

EDAX and FT-IR observations correlate with the compositions of SSP (cellulose, hemicelluloses, lignin, cutin, silica - Rafia and Gilani, 2001), BSP (holocellulose, cellulose, lignin, pectin - Li et al., 2010) and CFP ( $\alpha$-pinene, benzaldehyde, 1,8 cineole, furanoid, $\alpha$-campholenal, 4 -terpineol, $\alpha$-terpineol, $\alpha$-terpinyl acetate, spathulenol, caryophyllene-oxide, guaiol - Ogunwande et al., 2011). Presence of more number of peaks in CFP compared to SSP and BSP can be explained based on presence of good number of phytochemicals as mentioned above. The presence of functional groups like acid, alcohol and amine are evident from these studies. Protons of phenols/alcohols and carboxylic acid groups in these biosorbents facilitate them for participation in ion exchange. The physico-chemical parameters like TSS, TDS, pH etc were determined for the coffee processing waste water and were given in Table 1.

Table 1. Initial physico-chemical parameters of coffee processing waste water

\begin{tabular}{l|c|c|c|c|c|c}
\hline Parameter & COD & $\mathrm{N}$ & Fluoride & Phenolics & $\mathrm{pH}$ & TSS \\
\hline $\begin{array}{l}\text { Concentration } \\
\left(\mathbf{m g ~ l}^{-1}\right)\end{array}$ & $11300 \pm 208$ & 4.0 & Nil & Nil & $3.9-4.1$ & $3190 \pm 355$ \\
\hline
\end{tabular}

\subsection{Effect of contact time}

The percent of removal increased with an increase in contact time and reached maximum at 180 minutes by attaining equilibrium conditions (Fig. 3) and afterwards, sluggishness was observed which can be attributed to the saturation of biding sites. No decrease in percent of removal after optimum conditions showed the absence of desorption. Though, Muftah H. El-Naas et al., 2010 reported the maximum COD reduction in $30 \mathrm{~min}$, the adsorbent dose used by them was $20 \mathrm{~g} \mathrm{l}^{-1}$, whereas, it is $4 \mathrm{~g} \mathrm{l}^{-1}$ in the present case.

\subsection{Effect of Adsorbent dose}

With an increase in adsorbent dose, the percent reduction of COD increased, reached a maximum and then a slight decrease was observed (Fig. 4) which can be explained based on increase in number of pores/active sites as well as surface area with an increase in the amount of adsorbent (Rani devi et al., 2008). The maximum percent reduction of COD was $99.2 \%, 92.7 \%$ and $81.0 \%$ (with \pm 0.1 SD) using CFP, SSP and BSP respectively.

\subsection{Effect of $\mathrm{pH}$}

The $\mathrm{pH}$ of solution can influence the degree of ionization of functional groups present on active sites of adsorbent. Though, equilibrium $\mathrm{pH}$ affect the biosorption capacity, its maintenance is difficult and hence, initial $\mathrm{pH}$ of the solution was kept constant as it has an influence on equilibrium $\mathrm{pH}$. Moreover, sometimes, initial $\mathrm{pH}$ value of the solution has been shown to have more influence than the final $\mathrm{pH}$ (Waranusantigul et al., 2003). In earlier studies by other workers, it is clear that there is no significant effect of lower pH on the reduction of COD (Rani Devi et al., 2008) and hence, in the present case, study was carried out from $\mathrm{pH} 3$ onwards with 3 hours as contact time. With an increase in $\mathrm{pH}$, the percent of removal increased and reached maximum at neutral $\mathrm{pH}$ and then decreased (Fig. 5). Similar optimum pH at 7 and a fall in removal capacity afterwards was observed in the removal of COD from wastewater of coffee processing plant (Rani Devi et al., 2008; Rani Devi, 2010) and sugar industrial effluent (Parande et al., 2009). However, 
a slight enhancement in COD adsorption for $\mathrm{pH}$ values ranging from 7.5 to 8 was observed (Muftah $\mathrm{H}$. ElNaas et al., 2010) whereas, maximum COD removal was observed at pH 3.0-4.5 and $5.5-7.0$ using activated coconut shell and industrial grade granular activated carbon respectively (Mahesh et al., 1999).

A decrease in percent of $\mathrm{COD}$ removal beyond $\mathrm{pH} 7$ may be due to repulsion between the so generated negatively charged ions on adsorbent (by hydrolysis of phenol/alcohol and carboxylic acid) and in coffee waste water (by hydrolysis of various functional groups on biomolecules like pectin, fibers, fat, proteins, chlorogenic acid, lignins, tannins, humic acid). One more reasons for lower \% removal at pH above 7 might be the higher solubility of oligosaccharides in alkaline solutions (Rothfos 1979; Treagust, 1994). Similarly, at lower $\mathrm{pH}$, the presence larger number of $\mathrm{H}^{+}$ions neutralizes the negatively charged adsorbent surface and hence reduces COD removal by ion exchange (Tewari et al., 2005).

a.

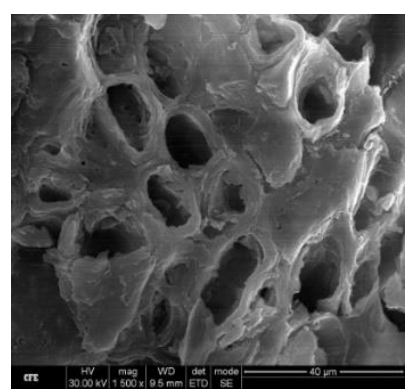

d.

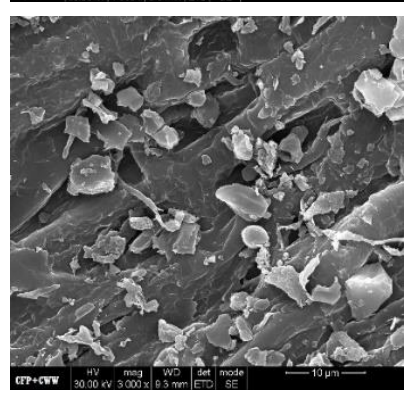

b.

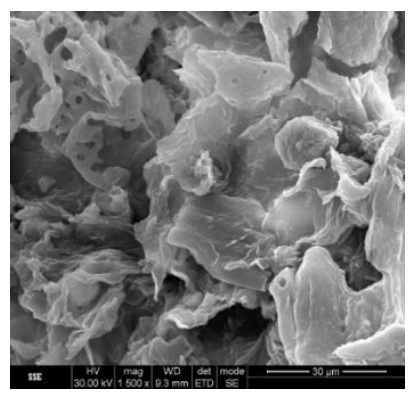

e.

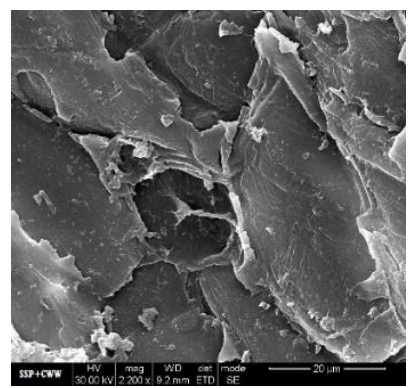

c.

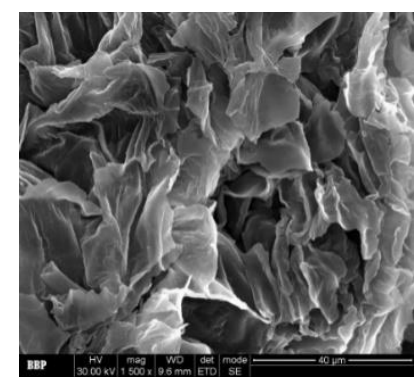

f.

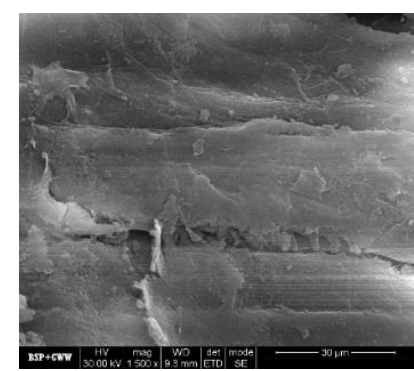

Figure 1. Scanning Electron Microscope images of untreated CFP, SSP and BSP ( $a, b$ and $c$ ) and after treatment effluent $(d, e$ and $f$ )

a.

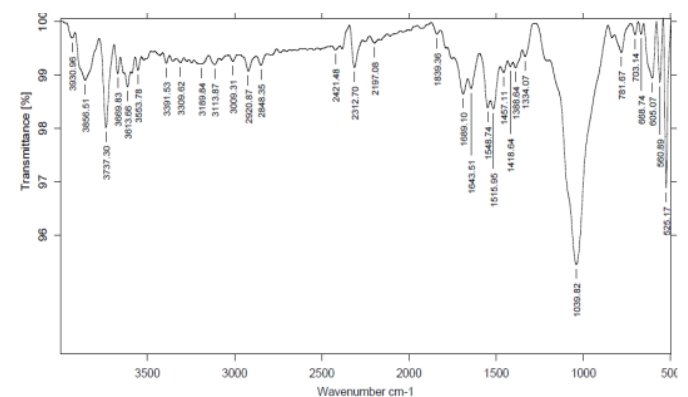

c.

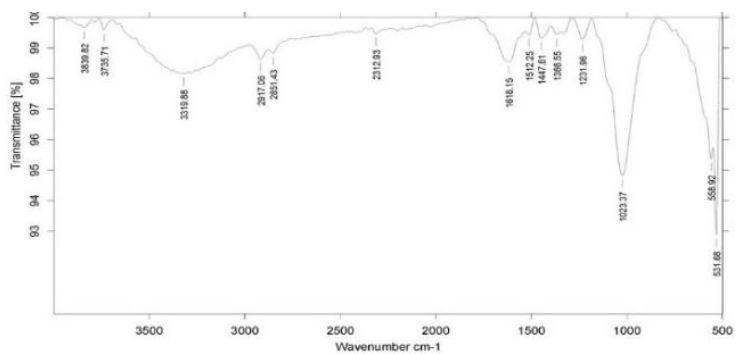

b.

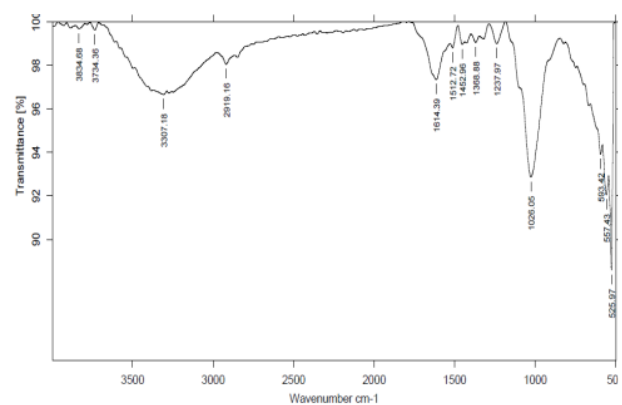

Figure 2. FT-IR spectra of three adsorbents (a) CFP and (b) SSP (c) BSP 


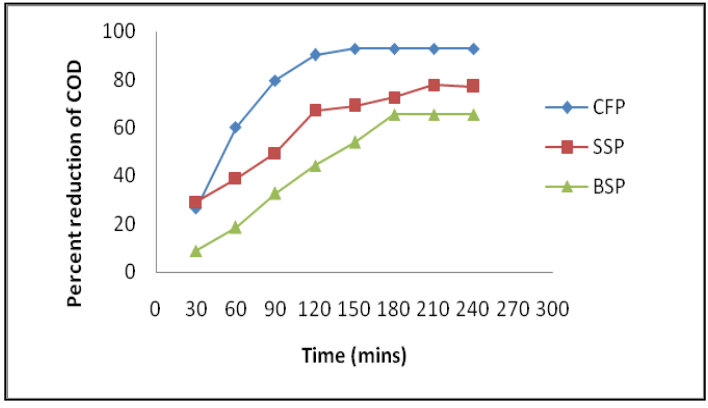

Figure 3. Effect of contact time on percent reduction of $C O D$

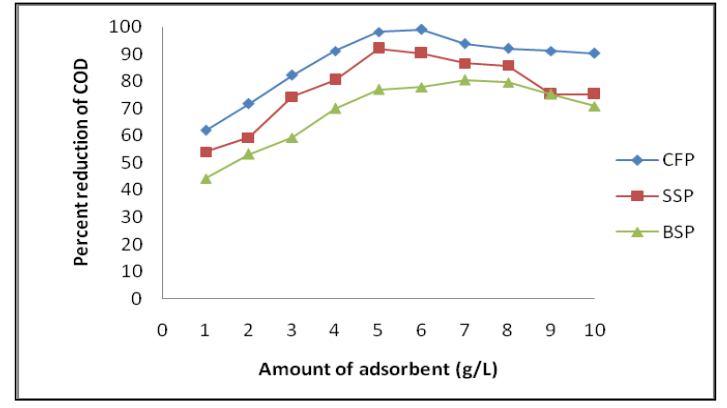

Figure 4. Effect of adsorbent dose on percent reduction of COD

\subsection{Effect of $\mathrm{pH}$}

As the percent removal is maximum at $\mathrm{pH} 7$, neutralization of coffee industry effluents has to be carried out prior to COD removal in adsorption methods because, recycling of the pulping water causes an increase in organic matter which ferments rapidly to produce organic acids leading to an increase in acidity $(\mathrm{pH}=4.3)$ (Adams and Dougan, 1987).

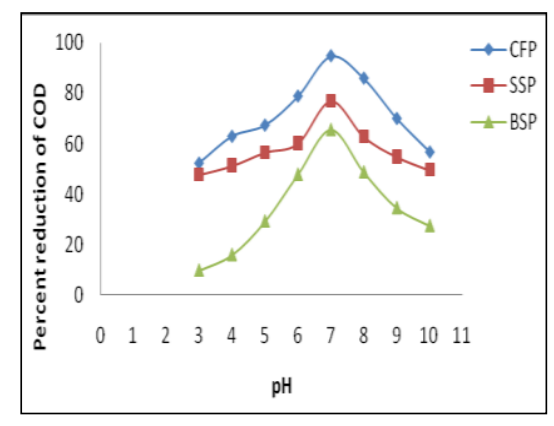

Figure 5. Effect of $\mathrm{pH}$ on $\%$ reduction of COD

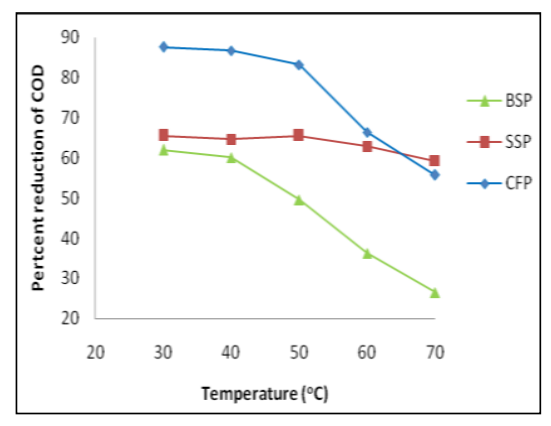

Figure 6. Effect of temperature on \%reduction of COD

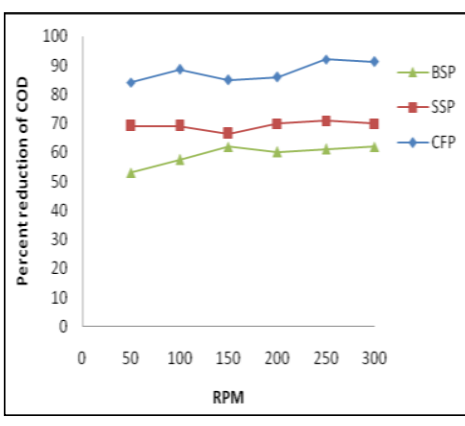

Figure 7. Effect of agitation on \%reduction of COD

\subsection{Effect of Temperature}

In general, preferable binding can be expected at higher temperatures for endothermic reactions, however, higher removal efficiencies are observed for exothermic reactions at lower temperatures. In the present case, a decrease in the adsorption percentage with an increase in temperature was observed with 3 hours as contact time. (Fig. 6). Though, this seems to be corroborates with the well known fact that sorption capacity is expected to decrease with an increase in solution temperature when sorption process is exothermic, the present case involves both physical and chemical adsorptions. Such simultaneous occurrence of both adsorptions was reported by (Ho and McKay 2003, Panday et al., 1985).

Mostly, in the case of chemisorption, an increase in temperature increases adsorption capacity due to (i) increase in the kinetic energy of the adsorbate (ii) expansion of the pores within the adsorbent particles (Muftah H. El-Naas et al., 2010) and (iii) swelling effect which enable to penetrate further (M. Do gan, M. Alkan, 2003). However, even in chemisorption, a decrease in removal capacity at an increased temperature can be explained based on (i) increased escaping tendency of already adsorbed molecules from adsorbent into the bulk solution due to increase in total energy of sorbate molecules at higher temperature (Sharma et al., 1991) and (ii) dissolution of sorbing solution because, tannins and other phenol / alcohol compounds are soluble at high temperatures (Jin Dai and Russell J. Mumper, 2010). However, (Weber and Chakravorti, 1974) has stated that, since diffusion is an endothermic process, the rate of sorption will increase with increased solution temperature when intraparticle transport (pore diffusion) is the ratelimiting step. The results of this study on the effect of temperature indicate it is possible that this pseudo- 
second-order model could act as a methodology for discriminating between sorption mechanisms on this basis.

Thermodynamic parameters $\left(\Delta \mathrm{G}, \Delta \mathrm{H}\right.$ and $\left.\Delta \mathrm{S} \mathrm{KJ} \mathrm{mol}{ }^{-1}\right)$ at $303 \mathrm{~K}$ are $\left(-1.69,-34.17\right.$ and $-0.10 \mathrm{KJ} \mathrm{mol}^{-1}$ for BSP), (-5.58, -39.74 and $-0.11 \mathrm{KJ} \mathrm{mol}^{-1}$ for SSP) and $\left(-1.71,-5.13\right.$ and $-0.01 \mathrm{KJ} \mathrm{mol}^{-1}$ for CFP). The activation energy Ea is calculated using Arrhenius equation. By plotting log $k^{2}$ versus $1 / T$ activation energy for dye adsorption is calculated as $19.65 \mathrm{~kJ} \mathrm{~mol}^{-1}$. As activation energy is lower than $40 \mathrm{~kJ} \mathrm{~mol}^{-1}$, it follows that the reaction is physical adsorption controlled process (Chowdhury et al., 2009; Jaman et al., 2009). Activation energy in the range of 17-21 KJ mol${ }^{-1}$ and $21-42 \mathrm{KJ} \mathrm{mol}^{-1}$ indicates that the type of diffusion path of sorption process is film diffusion and pore diffusion respectively (Namsivayam and Sangeetha, 2006). Hence, in the present case, the diffusion is mostly pore diffusion.

\subsection{Effect of agitation}

In the case of BSP and SSP, no effect of agitation on the removal of COD was observed with 3hours as contact time. But, a slight initial increase in adsorption capacity was noted in the case of CFP (Fig. 7), due to improved diffusion of sorbate towards sorbent and a decrease in film resistance to mass transfer surround the adsorbent particles with an initial increase in agitation. A slight oscillatory nature in adsorption capacity at higher agitation speeds can be explained based on the competition between improved diffusion and desorption of sorbate due to centrifugal force / mass transfer resistance contributes at higher agitations (Crini et al., 2007).

\subsection{Adsorption Isotherm studies}

Langmuir, Freundlich and D-R isotherms were employed at the pre-determined equilibrium conditions in order to analyze the interaction of adsorbate on the surface of each adsorbent (Table.2). Based on the values of $b / R_{L}$, Langmuir equation is favorable $\left(0<R_{L}<1\right)$ or unfavorable $\left(R_{L}>1\right)$. Similarly, the value of sorption intensity $(1<n<10)$ indicates that sorption is Freundlich favorable. As the $R_{L}$ values in the present case are in the range of $0.011-0.016$ and ' $n$ ' values are less than 10, the three adsorbents (CFP, SSP and BSP), Langmuir as well as Freundlich isotherms are favorable for adsorption process, whereas, based on the values of regression coefficients, it is clear that Langmuir isotherm fit relatively better than the Freundlich isotherm. Hence, both mono and multilayer adsorptions occur in the present studies with preference to monolayer adsorption. A similar observation on data confirmation to combination of mechanisms - Freundlich and Langmuir isotherms was reported in reduction of COD in sugar industrial effluent (Parande et al., 2009) and removal of dyes (Ho and McKay et al., 2003).

Table 2. Adsorption isotherm parameters of three adsorbents, CFP, SSP and BSP

\begin{tabular}{ccccc}
\hline Isotherm & Parameter & CFP & SSP & BSP \\
\hline Langmuir & $\mathbf{b}\left(\mathbf{~ m g}^{-1}\right)$ & 0.044 & 0.065 & 0.060 \\
\hline & $\mathbf{q}_{\mathbf{m}}\left(\mathbf{m g ~ g}^{-1}\right)$ & 27.78 & 28.57 & 62.50 \\
\hline Freundlich & $\mathbf{R}^{\mathbf{2}}$ & 0.685 & 0.909 & 0.996 \\
\hline & $\mathbf{n}$ & 1.252 & 3.559 & 9.091 \\
\hline $\mathbf{D}-\mathbf{R}$ & $\mathbf{k}_{\mathbf{F}}$ & 27.91 & 8.48 & 4.45 \\
\hline & $\mathbf{R}^{\mathbf{2}}$ & 0.420 & 0.766 & 0.861 \\
\hline & $\mathbf{q}_{\mathbf{D}}\left(\mathbf{m g ~ g}^{-1}\right)$ & 1644.21 & 1203.51 & 582.39 \\
\hline $\mathbf{B}_{\mathbf{D}}$ & -0.137 & -0.934 & -3.316 \\
\hline & $\mathbf{R}^{\mathbf{2}}$ & 0.524 & 0.877 & 0.908 \\
\hline
\end{tabular}

\subsection{Adsorption kinetics}

The mechanism of action of adsorbate-adsorbent interactions has been analysed in terms of pseudo first order (Lagergren et al., 1898) and pseudo second order sorption (Ho and McKay, 1999) equations.

In the case of linearized pseudo-first order equation, it is observed that the results deviate significantly from a straight line, which indicates that the pore diffusion is not the sole rate controlling step. Moreover, the deviation of the values of $R^{2}$ from unity is a measure of the incompatibility of each respective case. In 
the present case, the first order kinetics show poor correlation coefficients. On the other hand, when $t / q$ was plotted against $t$, according to the linearized pseudo-second order model, a clear linear relationship was observed for all cases. The data were fitted perfectly well by straight lines, with $R^{2}$ values in the range of 0.993 to 0.999 . This proves that the adsorption kinetics is more accurately described by pseudo-second order model. Higher values of regression coefficient $\mathrm{R}^{2}$ were observed for second order kinetics compared to first order. In addition, the qe values (calculated) from pseudo-second-order model agree perfectly with the experimental $\mathrm{q}_{\mathrm{e}}$ values (Table.3). Pseudo-second order kinetic data reveal the mechanism of adsorbate and adsorbent interaction as chemical coordination in additon to physical attachment. Moreover, the correlation coefficients $\left(R^{2}\right)$ for the pseudo-second order kinetic model are much greater than the intraparticle diffusion coefficients which strongly suggest a chemical reaction mechanism (Tables. 3 and 4).

Table 3. Adsorption kinetic parameters, of adsorbents, CFP, SSP and BSP

\begin{tabular}{|c|c|c|c|c|c|c|c|}
\hline \multirow{2}{*}{$\frac{\text { Adsorbent }}{\text { Sample }}$} & \multirow[b]{2}{*}{$q_{e} \mathrm{mgg}^{-1}(\exp )$} & \multicolumn{3}{|c|}{ First order } & \multicolumn{3}{|c|}{ Second order } \\
\hline & & $\begin{array}{c}\mathrm{q}_{\mathrm{e}} \mathrm{mgg}^{-1} \\
\text { (cal) }\end{array}$ & $\mathrm{K} \min ^{-1}$ & $\mathbf{R}^{2}$ & $\begin{array}{c}\mathrm{q}_{\mathrm{e}} \mathrm{mgg}^{-1} \\
\text { (cal) }\end{array}$ & $\begin{array}{c}\mathrm{H} \\
\left(\mathrm{mgg}^{-1} \min ^{-1)}\right.\end{array}$ & $\mathbf{R}^{2}$ \\
\hline CFP/5 $\mathrm{g} \mathrm{I}^{-1}$ & 23.20 & 2.69 & 0.009 & 0.810 & 28.6 & 1.25 & 0.997 \\
\hline CFP $/ 10 \mathrm{~g} \mathrm{I}^{-1}$ & 35.00 & 1.76 & 0.005 & 0.800 & 37.0 & 5.71 & 0.997 \\
\hline CFP/20 $\mathrm{g} \mathrm{I}^{-1}$ & 63.45 & 1.87 & 0.012 & 0.995 & 66.7 & 18.52 & 0.999 \\
\hline $\mathrm{SSP} / 5 \mathrm{~g} \mathrm{I}^{-1}$ & 25.00 & 1.92 & 0.005 & 0.500 & 28.6 & 1.99 & 0.993 \\
\hline SSP/10 $\left.\right|^{-1}$ & 47.30 & 2.05 & 0.016 & 0.921 & 50.0 & 11.11 & 0.999 \\
\hline SSP/20 $\left.\right|^{-1}$ & 67.30 & 2.09 & 0.018 & 0.977 & 71.4 & 23.36 & 0.999 \\
\hline $\mathrm{BSP} / 5 \mathrm{~g} \mathrm{|}^{-1}$ & 45.60 & 2.01 & 0.012 & 0.750 & 47.6 & 9.27 & 0.998 \\
\hline $\mathrm{BSP} / 10 \mathrm{~g} \mathrm{I}^{-1}$ & 48.20 & 1.44 & 0.005 & 0.899 & 50.0 & 16.49 & 0.999 \\
\hline $\mathrm{BSP} / 20 \mathrm{~g} \mathrm{|}^{-1}$ & 57.20 & 1.48 & 0.007 & \begin{tabular}{|l|}
0.750 \\
\end{tabular} & 58.8 & 23.81 & 0.999 \\
\hline
\end{tabular}

Similarly, in the reduction of COD in refinery wastewater on date-pit activated carbon, kinetic data were best fitted by the pseudo-second order model, and the equilibrium data followed the Langmuir monolayer isotherm (Muftah H. El-Naas et al., 2010).

\subsection{Boyd, Weber's and Elovich models in support of adsorption mechanism}

To investigate the mechanism of adsorption, the kinetic data obtained for the adsorption were evaluated using Boyd's kinetic model (Boyd et al., 1947) and Weber's intraparticle model (Weber and Morris, 1963). Though Boyd plots were reasonably linear $\left(R^{2}=0.902,0.949\right.$ and 0.938$)$, but have intercepts, hence, internal diffusion may not be the sole rate controlling step in the adsorption process (Poots et al., 1976).

Table 4. Weber's intraparticle, Boyd and Elovich's adsorption kinetic parameters, of adsorbents, CFP, SSP and BSP

\begin{tabular}{|c|c|c|c|}
\hline Adsorbent & CFP & SSP & BSP \\
\hline \multicolumn{4}{|c|}{ Weber's Intraparticle diffusion } \\
\hline $\mathbf{k}_{\mathbf{d}}$ & 174.4 & 147.9 & 180.3 \\
\hline$q$ & 270.90 & 48.65 & -759.80 \\
\hline $\mathbf{R}^{2}$ & 0.789 & 0.946 & 0.967 \\
\hline \multicolumn{4}{|c|}{ Boyd model } \\
\hline $\mathbf{R}^{2}$ & 0.938 & 0.949 & 0.902 \\
\hline \multicolumn{4}{|c|}{ Elovich's kinetics } \\
\hline$\alpha\left(\mathrm{mg} \mathrm{g}^{-1} \mathrm{~min}^{-1}\right)$ & 92.48 & 66.55 & 32.45 \\
\hline $1 / \beta\left(\mathrm{mg} \mathrm{g}^{-1}\right)$ & 909.80 & 728.10 & 877.80 \\
\hline$R^{2}$ & 0.896 & 0.958 & 0.957 \\
\hline
\end{tabular}

Multi-linearity in Weber's plots indicates the involvement of more than one kinetic stage. Mainly three 
stages were observed viz., diffusion of sorbate to sorbent (fast stage), intra particle diffusion (delayed) and diffusion through small pores (establishment of equilibrium). This trend is similar to that observed by Chen and Liu, (2012). However, in the reduction of COD in refinery wastewater on date-pit activated carbon, modeling of the controlling mechanisms indicated that both intrinsic kinetics and mass transfer contributed to controlling the adsorption process. Mass transfer seemed to be the dominant mechanism at low COD content, while intrinsic kinetics dominates at high concentrations (Muftah $\mathrm{H}$. El-Naas et al., 2010).

The Elovich equation was also satisfied with reasonable linearity supporting involvement of chemisorptions as the one of the mechanism and $\alpha$ (initial sorption rate) as well as $\beta$ (related with extent of surface coverage and activation energy for chemisorption) are tabulated (Table.4).

The comparison of the percent of COD removal in the present study with earlier studies show that Casuarina fruit powder and Sorghum stem powder work extremely well, whereas, Banana stem powder is reasonably acceptable.

\begin{tabular}{|c|c|c|}
\hline Adsorbent & \%COD reduced & Reference \\
\hline Avacado peel carbon & 98.2 & Rani Devi et al., 2008 \\
\hline Tamarind nut carbon & 70.0 & Parande et al., 2009 \\
\hline Dates nut carbon & 72.2 & Parande et al., 2009 \\
\hline Metakaolin & 75.3 & Parande et al., 2009 \\
\hline Crushed burnt coal & 85.0 & Debabrata, 2011 \\
\hline Fly ash & 25.0 & Lakdawala \& Lakdawala, 2012 \\
\hline Coconut coir activated carbon & 80.0 & Kulkarni, 2013 \\
\hline Casuarina fruit powder & 99.2 & Current study \\
\hline Sorghum stem powder & 92.7 & Current study \\
\hline Banana stem powder & 81.0 & Current study \\
\hline
\end{tabular}

\section{Conclusion}

The maximum adsorption efficiencies of the three adsorbents for COD removal from coffee waste water were $99.2 \%, 92.7 \%$ and $81.0 \%$ using CFP, SSP and BSP respectively. The order of adsorption efficiency was CFP $>$ SSP $>$ BSP can be correlated with their microporous structures, where, CFP sample surface consists of cavities indicating high possibility of adsorption. The proposed involvement of chemisorption was correlated with the possible interactions between functional groups present on biosorbents and sorbates (contributing to COD in coffee waste water). Langmuir isotherm fit relatively better than the Freundlich isotherm and the adsorption data showed good agreement with the pseudo-second-order kinetic model. But at the same time, the adsorption capacity decreased with an increase in temperature, indicating endothermic nature of adsorption. Based on the observations, both mono and multilayer adsorptions occur in the present studies with preference to monolayer adsorption. Considering the fact that these three adsorbents are abundantly available, the efficient reduction of COD from wastewater could be achieved by utilizing these adsorbents industrially.

\section{Acknowledgements}

The authors are highly thankful to Acharya Nagarjuna University, Guntur for supporting this research work. The authors are also thankful to Sophisticated Analytical Instrumentation Facility, IIT-Madras for kindly providing instrumental facility to conduct some part of this work.

\section{References}

Adams M.R. and Dougan J. (1987), Coffee technology. John Wiley and sons, New York.

Alemayehu Haddis and Rani Devi (2008), Effect of effluent generated from coffee processing plant on the water bodies and human health in its vicinity, J. Hazrd. Mater., 152, 259-262. 
ASTM (1972), Annual book of ASTM standards part - 23, American society for testing and materials, Philadelphia.

Boyd G.E., Adamson A.W. and Myers-Jr L.S. (1947), The exchange adsorption of ions from aqueous solutions by organic zeolites, II: Kinetics, J. Am. Chem. Soc., 69, 2836-2848.

Calzada F., Garcia R., Porres C. and Rolz C. (1989), Integrated utilization of coffee processing byproducts and wastes, In: International Biosystems (II). CRC Press, Boca Raton, USA.

Chen G.F. and Liu M.H. (2012), Adsorption of L-lysine from aqueous solution by spherical lignin beads: Kinetics and equilibrium studies, Bioresources, 7(1), 298-314.

Chen J.P. and Yang L. (2005), Chemical modification of Sargassum sp.for prevention of organic leaching and enhancement of uptake during metal biosorption, Ind. Eng. Chem. Res., 44, 9931-9942.

Chowdhury A., Sarkar A.D. and Bandyopadhyay A. (2009), Rice husk ash as a low cost adsorbent for the removal of methylene blue and congo red in aqueous phases, Clean Soil, Air, Water, 37(7), 581-591.

Crini G., Peindy H.N, Gimbert F. and Robert F. (2007), Removal of C.I. Basic Green 4 (Malachite Green) from aqueous solutions by adsorption using cyclodextrin-based adsorbent: kinetic and equilibrium studies, Sep Purif Technol., 53(1), 97-110.

Debabrata M. (2011), Process evaluation and treatability study of wastewater in a textile dyeing industry, International Journal of Energy and Environment, 2(6), 1053-1066.

Fresner J. and Schnitzer H., (1996), How coffee-making can help one understand cleaner production, J. Cleaner Prod., 4(3-4), 213-217.

Freundlich H. (1924), The Elements of Colloidal Chemistry, translated by George Barger, Dutton and Company Publishers, New York, pp. 58-61.

Ho Y.S. and McKay G. (1999), Pseudo-second order model for sorption processes, Process Biochem., 34, $451-465$.

Ho Y.S. and McKay G. (2003), Sorption of dyes and copper ions onto biosorbents, Process Biochem., 38, $1047-1061$.

Jaman H., Chakraborty D. and Saha P. (2009), A study of the thermodynamics and kinetics of copper adsorption using chemically modified rice husk, Clean-Soil, Air, Water, 37, 704-711.

Jin Dai and Russell J. Mumper (2010), Plant Phenolics: Extraction, Analysis and Their Antioxidant and Anticancer Properties, Molecules, 15, 7313-7352.

Kulkarni S.J. (2013), Removal of organic matter from domestic waste water by adsorption, International Journal of Science, Engineering and Technology Research, 2(10).

Lagergren S. (1898), On the theory of so-called adsorption solutes, The Royal Swedish Academy of Sciences, Handlingar, 24(4), 1 - 39 (in German).

Lakdawala M.M. and Lakdawala J.M. (2012), Adsorption study of BOD content from Sugar Industry waste water by low cost material Fly ash. Der Chemica Sinica, 3(2), 497-502.

Li K., Fu S., Zhan H., Zhan Y. and Lucia I. (2010), Analysis of the chemical composition and morphological structure of banana pseudo-stem, Bioresources, 5(2), 576-585.

Mahesh S., Gowda CH. and Sujan R.P. (1999), Color tannin removal from coffee curing industrial effluents using adsorbents-IGGAC and ACS, J. Pollution Res., 18(1), 13-19.

Mburu J.K., Thuo J.T. and Marder R.C. (1994), The characterization of wastewater from coffee processing factories in Kenya, Kenya Coffee, 59, 1757-1763.

Muftah H. El-Naas, Sulaiman Al-Zuhair and Manal Abu Alhaija (2010), Reduction of COD in refinery wastewater through adsorption on date-pit activated carbon, J. Hazrd. Mater., 173, 750-757.

Namsivayam C. and Sangeetha D. (2006), Removal and recovery of vanadium(V) by adsorption onto $\mathrm{ZnCl}_{2}$ activated carbon: Kinetics and isotherms, Adsorption, 12, 103-117.

Ogunwande I.A., Flamini G., Adefuye A.E., Lawal N.O., Moradeyo S. and Avoseh N.O. (2011), Chemical compositions of Casuarina equisetifolia L., Eucalyptus toreliana L. and Ficus elastica Roxb. ex Hornem cultivated in Nigeria, $S$ Afr J Bot., 77, 645-649.

Panday K.K., Prasad G. and Singh V.N. (1985), Copper(II) removal from aqueous solution by fly ash, Water Res., 19, 869-873.

Parande A.K., Sivashanmugam A., Beulah H. and Palaniswamy N. (2009), Performance evaluation of low cost adsorbents in reduction of COD in sugar industrial effluent, $J$ Hazard Mater., 168(2-3), 800-805. 
Poots V.J.P., McKay G. and Healy J.J. (1976), The removal of acid dye from effluent, using natural adsorbents-II wood, Water Res., 10, 1067-1070.

Rafia F. and Gilani A.H. (2001), Changes in chemical composition of sorghum as influenced by growth stage and cultivar, Asian-Australasian Journal of Animal Sciences, 14(7), 935-940.

Ramesh S.T., Gandhimathi R., Elavarasi T.E., Isai Thamizh R., Sowmya K. and Nidheesh P.V. (2014), Comparison of methylene blue adsorption from aqueous solution using spent tea dust and raw coir pith, Global NEST Journal, 16(1), 146-159.

Rani Devi (2010), Innovative Technology of COD and BOD reduction from coffee processing wastewater using avocado seed carbon (ASC), Water Air Soil Pollut, 207, 299-306.

Rani Devi, Vijender Singh and Ashok Kumar (2008), COD and BOD reduction from coffee processing wastewater using Avacado peel carbon, Bioresource Techn., 99(6), 1853-1860.

Rothfos B. (1979), Kaffee. Die Produktion. Hamburg.

Selvamurugan M., Doraisamy P. and Maheswari M. (2010), An integrated treatment system for coffee processing wastewater using anaerobic and aerobic process., Ecol. Eng., 36(12), 1686-1690.

Sharma Y.C., Prasad G., and Rupainwar D.C. (1991), Removal of Ni(II) from aqueous solutions by sorption, Int J Environ Stud., 37,183-191.

Tallontire A. (2002), Challenges facing fair trade: which way now? Small Enterprise Development, 13(3), 12-24.

Tewari N., Vasudevan P. and Guha B.K. (2005), Study on biosorption of Cr(VI) by Mucor Hiemalis, Biochemical Eng J., 23, 185-192.

Treagust J. (1994), Coffee Waste Water Treatment. In: B.Sc. (Hons.) dissertation, Cranfield University, UK.

Verma V.K. and Mishra A.K. (2010), Kinetic and isotherm modeling of adsorption of dyes onto rice husk carbon, Global NEST Journal, 12(2), 190-196.

Von Enden J.C. (2002), Best practices at wet processing pay financial benefits to farmers and processors, GTZ-PPP Project on Improvement of coffee quality and sustainability of coffee production in Vietnam.

Waranusantigul P., Pokethitiyook P., Kruatrachue M. and Upatham E.S. (2003), Kinetics of basic dye (methylene blue) biosorption by gaint duckweed (Spirodela polyrrhiza), Environ Pollut., 112, 385-392.

Weber T.W. and Chakravorti R.K. (1974), Pore and solid diffusion models for fixed-bed adsorbers, AIChE Journal, 20(2), 228-238.

Weber W.J. and Morris J.C. (1963), Kinetics of adsorption on carbon from solution, J. Sanitary Eng. Div. Proceed. Am. Soc. Civil Eng., 89, 31-59.

WHO (1995), Guideline for Discharge of Industrial Effluent Characteristics, vol. 3, WHO, Geneva. 